\title{
Editorial
}

\section{Cambridge symposium on economic crime}

Over the past few years, governments and now the compliance industry appear to have woken up to the practical importance of financial intelligence. Of course, the significance of knowing who pays for what and where they keep their money was not lost on Nero, so this is nothing new. Indeed, at a meeting of ministers of justice and senior law officers in Winnipeg, Canada in 1977, concern was expressed about the vulnerability of, in particular, developing and more fragile economies to the threat of serious economically motivated crime and organised crime. Ministers expressed the view that in combating what was seen to be the destabilising agenda of the increasingly isolated Republic of South Africa, more attention need to be given to the economic aspects of crime. A major review of the then existing arrangements for mutual legal assistance and co-operation between law enforcement and other relevant agencies was commissioned by the British Government, Commonwealth Secretariat and General Secretariat of ICPO-Interpol. The findings and recommendations of this review were received by Commonwealth ministers and attorneys general in Barbados in May 1980. It was recognised that the then conventional mechanisms for co-operation were inadequate in protecting vulnerable economies and merely police force to police force did not work. Indeed, in many resources relevant to combating economically motivated crime were outside the police and consequently the Interpol network. As a direct result of this, a special unit was established within the Commonwealth Secretariat, with full diplomatic immunity, to spearhead at an intelligence level the better collaboration and co-operation between not just traditional police agencies but all agencies concerned with promoting stability and security in the context of economic crime and related activity. In many respects, this unit was the first financial intelligence unit and certainly the first to operate at a supra-national level.

In an attempt to bring together those individuals and organisations concerned with promoting the prevention and disruption of economic crime and especially organised crime, a conference was organised with the support of the University of Cambridge in 1982, at Jesus College, Cambridge. This was the first Cambridge international symposium on economic crime and was attended by 156 participants from 25 countries. The 35th symposium took place in Jesus College, during the first week of September 2017, and had well over 1,800 participants from over 100 countries. Participants included ministers, legislators, senior officials, regulators, law enforcement, intelligence and security personnel, diplomats, judges, prosecutors, academics and many in the business and financial sectors and those who professionally advise them. Last year, the symposium as its primary theme questioned where in preventing and controlling economically motivated misconduct the "buck stopped". This year, the symposium questioned whether those responsible were up to the job. Of course, notwithstanding the importance of the overarching theme, over 50 specialist workshops focused on a wide range of other issues including, for example, legal professional privilege, debarment regimes and big data. Over the past 35 years, there have been numerous and significant developments in all aspects of addressing the threats presented by economic crime. However, one concern that repeatedly manifested itself throughout this year's symposium was the need for personal contacts, which could facilitate trust and thus facilitate meaningful co-operation over and above all the developments that have occurred in institutionalising mutual assistance and improving the efficacy and integrity of communication. While perhaps gratifying for those who have been involved in the symposia over the years, it is perhaps surprising that in many ways we have come full

Journal of Financial Crime Vol. 25 No. 1, 2018 pp. 2-4

(C) Emerald Publishing Limited 1359-0790

DOI 10.1108/JFC-10-2017-0089 
circle in recognising that at all levels of inter-agency interface, whether domestic or transnational, human beings require personal contact, perhaps albeit indirect, to provide that vital element of trust for commitment.

Prosecutors from numerous jurisdictions underlined the practical advantages of having not only adequate mutual assistance arrangements in place but also having a direct line to someone in the relevant jurisdiction with whom they can communicate on a timely basis. The importance of placing prosecutors and or investigators overseas in missions and embassies was emphasised, albeit for many this is a luxury beyond their resources. The placing of legal attaches in key embassies, pioneered by the US Justice Department many years ago, has now been emulated by a number of governments. However, in the context of smaller and less well-endowed jurisdictions there was considerable discussion within the symposium about the use of multi-agency and trans-national task forces. Again, this is not new. The General Secretariat of ICPO-Interpol convened special task groups in the 1980s, and this approach was also adopted by the Commonwealth. An interesting development is the collaboration between such teams and private sector lawyers and investigators involved in pursuing the assets of corrupt officials and politicians. While again this was explored years ago by the Commonwealth unit, the availability of financial assistance and support from inter-governmental organisations and individual governments, including the UK, together with imaginative funding arrangements for private lawyers has made a big difference. While the amounts actually recovered are less impressive than many had hoped for, these initiatives do send out a salutary message.

Of particular note in recent years has been the concern and willingness of China to engage in debate on and to an increasing degree action against trans-national economic crime. China has long recognised the dangers to stability and development presented by economically motivated crime and in large measure the present campaign against corruption reflects this. The practical difficulties that Chinese investigators and especially prosecutors have faced in this context in securing effective co-operation from many overseas authorities has led to more attention being given, at the highest levels of government, to fostering better facilities for mutual legal and regulatory co-operation. An illustration of this is the request from a number of authorities within China to join with the Cambridge symposium in exploring the risks that might be encountered in China's one belt one road strategy. Consequently, within this year's symposium, a conference entitled "One belt one road initiative - the new Silk Road - The road to sound, stable and honest business" was organised at Jesus College, Cambridge. This parallel programme attracted well over 120 participants from China including diplomats, officials and representatives from business organisations. A number of non-Chinese experts were constructively blunt in their articulation of the risks, as they see it, facing this ambitious long-term project. In particular, concern was expressed as to the adequacy of the Chinese legal system and business laws in supporting this initiative. The Chinese Government is aware of the need to improve both the content of certain laws and their administration. For example, over the past couple of years, members of both the people's Supreme Court and our Supreme Court have met regularly in a "round-table" discussion, which has focussed on a number of issues relating to substantive law and dispute resolution. A high-level team of legislative draftsmen from the People's Congress has also received training within the UK.

In his discussions with President Xi Jinping, the then Prime Minister David Cameron addressed how inter alia the UK might better assist China in fostering a legal system, which is better able to serve China's increasing role as one of the world's leading economies. Of course, there have been specific projects for many years relating to judicial training and the like. It is also the case that while China is a traditional civil law jurisdiction, it has 
particularly in the context of opening its economy been influenced by legal models from common law countries. However, what is now being put in place is rather more ambitious and is being supported by the UK Prosperity Fund. In part, numerous initiatives are based on the notion that the common law is more facilitative of trade and commerce and better promotes the rule of law. While this might be debated, China has been receptive to technical and other assistance in this regards. For example, there are experiments taking place within China involving greater application of common law principles and procedures in dispute resolution. Indeed, special "common law friendly" courts are being established to address commercial and financial disputes "around" Hong Kong. In several major cities, there are pilot projects adapting the civilian criminal procedure to one more recognisable by common lawyers. There are also significant, albeit so far of limited practical success, developments in legal education and practice.

While China recognises that the UK's intentions are not entirely selfless and are increasingly mandated by trade-related considerations, the willingness of Chinese officials to consider "reforms" that would 10 years ago have appeared revolutionary is commendable. The important role that the Chinese Communist Party has played in promoting stability, both politically and economically, is a crucial factor, and it seems that it wishes to re-assert its guiding influence in areas such as the supervision of banks and other financial institutions. In recent months, the anti-corruption campaign has been taken into the financial sector. Before then, it was largely albeit by no means exclusively, confined to officials - in both government and the party. Now investigators from both the Party and the Supreme People's Procuratorate are pursuing a number of senior bank officials and directors and also regulators. The Party is also strengthening its involvement in the selection and monitoring of the management of many key financial institutions. While some in the West may well look askance at these developments, it was pointed out by many commentators at the symposium that our own models of governance have failed in recent history. In the context of China, the importance of ensuring that the financial institutions and markets are responsive to the ambitious programme for development and contribute to the overriding objective of stability is non-negotiable. 